TARBIYA: Journal of Education in Muslim Society, 2(1), 2015, 97-104

\title{
DEBATE AS A LEARNING-TEACHING METHOD: A SURVEY OF LITERATURE
}

\section{Arskal Salim}

LPPM: Research and Community Outreach, Syarif Hidayatullah State Islamic University of Jakarta, Indonesia E-mail: arskal.salim@uinjkt.ac.id

Received: $25^{\text {th }}$ January 2015; Revised: $17^{\text {th }}$ March 2015; Accepted: $15^{\text {th }}$ May 2015

\section{Abstract}

This present paper explored historical references of debate trend to be proposed as one of learningteaching method. By analyzing the strengths and limitations of debate, the author found that any existing debate format is imperfect and it is educators' task to seek out how in utilizing debate as a learning teaching method. Some works on debate assessment method were described. In real implementation, on author's experience to use debate as learning-teaching method, showed that it was difficult to mark students either as individual or team. Therefore, their preparation and the performance in-class debate should be considered.

Keywords: debate as a learning-teaching; learning-teaching method

\section{Abstrak}

Artikel ini mengeksplorasi referensi sejarah dari tren debat yang akan diusulkan sebagai salah satu metode belajar mengajar. Dengan menganalisis kekuatan dan keterbatasan perdebatan, penulis menemukan bahwa format debat yang ada tidak sempurna dan itu adalah tugas pendidik untuk mencari tahu bagaimana memanfaatkan debat sebagai metode pengajaran pembelajaran. Beberapa karya pada metode penilaian debat dijelaskan. Dalam implementasi nyata, pengalaman penulis menggunakan debat sebagai metode belajar-mengajar, menunjukkan bahwa hal itu sulit untuk menandai siswa baik sebagai individu atau tim. Oleh karena itu, persiapan mereka dan perdebatan kinerja dalam kelas harus dipertimbangkan.

Kata kunci: debat sebagai belajar-mengajar; Metode belajar-mengajar

How to Cite: Salim, A. (2015). Debate as A Learning-Teaching Method: A Survey of Literature. TARBIYA: Journal of Education In Muslim Society, 2(1), 97-104. doi:10.15408/tjems.v2i1.1665.

Permalink/DOI:http://dx.doi.org/10.15408/tjems.v2i1.1665 


\section{Introduction}

Debate as a part of public life and public policy has a long history. It is an ancient strategy to persuade or convince other people to accept one's opinion. Its development can be traced back as early as to the fifth century BCE, especially to the figure of Protagoras of Abdera. He was one of experts in rhetoric (the science of oratory) who could make the "worse (or weaker) argument appear the better (or stronger)" (Freely and Steinberg, 2005). Debate is necessary not only in the legislature, in the courtrooms or on the political campaign trail, but also in other area of society including in the university. In practical academic context, debate provides reasoned arguments for and against a proposition between two contending individuals or groups.

For many centuries, debate has been one of learning methods. It is a useful method that enables learners or students to actively engage in discussing a particular issue or finding resolutions to a problem. The initial growth of debate as one of modern educational methods took place throughout the $19^{\text {th }}$ and early $20^{\text {th }}$ century. The debate flourished as a modern teaching strategy thenceforth. Although it had declined in popularity for several decades in the mid of $20^{\text {th }}$ century, debate revived as teaching learning strategy in the 1980s when critical thinking was given a main emphasis in university academic life. It since then "continues to be a useful tool to develop skills in critical thinking, communication and logic" (Darby, 2007). This literature survey will investigate the extent to which existing scholarly works ponder positive and negative aspects of debate and its strengths and weaknesses as one of learning-teaching methods.

This survey will firstly present debate setting in various contexts. The next section will briefly discuss pros and cons concerning the general position of debate as a means of facilitating social interaction and decision-making procedures before then elaborating and analysing various literatures that support and/or criticise debate as a learning teaching method.

\section{(Dis)advantage of Debate}

Despite the fact that some scholars or teachers consider the variety of benefits of this method for academic learning, there are others who raise cautions and doubts regarding the effectiveness of debate for public life and as a learning-teaching method in particular.

Inspired by John Dewey, who argued that debate is fundamentally a top-down authority driven, undemocratic form of communication, through which the few manipulate the many (Ehninger, 1958), some scholars, like Flick (1998) and Tannen (1998), tend to characterise debate as a disease that infects democracy. Flick (1998) stated, "chronic debate is destructive, and despite our best intentions, it takes us down a path that leads in the opposite direction from where we say we want to go". Meanwhile, Tannen (1998) claimed that we exist in "a pervasive warlike atmosphere that makes us approach public dialogue, and just about anything we need to accomplish, as if it were a fight". Both Flick and Tannen paid attention more to the formal appearance of debate on the stage. They did not wisely take into account all efforts made before and during the debate. They seem to utilise a narrow scope definition of debate.

Other scholars opposed the opinion that debate is a disease or destructive and considered such opinion to be absurd (Busmek, 2009). For Busmek (2009), debate is fundamentally a cooperative and collaborative enterprise especially when it comes to specific roles played by participants involved in debate process: debaters facilitate significantly different communicative process; moderator acts a referee; conveners set rules and purpose of debate; and audience actively and critically participate in 
debate as well. Busmek's view was supported by Alfred Snider and Maxwell Schnurer (2002) who argue that debate is one of best educational methods since it is an engaging, stimulating, and illuminating practice that can help educate students and encourage them to take responsibility for their education. For both authors, if teachers, educators, students all over the world are searching for educational methods that are active, involve critical thinking, and ask students to integrate knowledge and improve communication skills; debate is certainly one of those methods. Snider and Schnurer (2002) acknowledged that debate is not the only way to teach these skills: communication by way of listening and speaking, argument construction, cooperative learning, critical thinking, research (traditional and computer), strategic note taking, logical organization, critical reading and evaluation. Yet, debate is useful in that it bundles many of them together into one activity.

\section{(Im)perfection of debate}

The idea that debate is an active and effective educational method is not shared by all. Some have opposed and criticised the use of debate as a method for learning and teaching. Nancy Tumposky (2004) identifies at least four flaws of debate as an instructional strategy. With all of this, she was questioning whether debate is a practical pedagogy to develop a variety of students' academic skills.

The first, debate tends to reinforce a bias toward dualism. This implies that instead of encouraging students to have multiple perspectives in any given issue, the in-class debate may provide students with only two bipolar views on any particular topic (yes or no; affirmative or negative). For this reason, Tumposky (2004) contended that "debate can oversimplify and misrepresent the nature of knowledge”.
The second, debate is inclined to direct students either to win or to lose in a debate session. For this reason, students often selectively look at particular aspects that only strengthen their own argument and ignore to consider exceptional cases in which might be contrary to or weaken their argument. In addition, students tend not to make concessions or qualifications.

The third, debate inherently requires the two contending sides to justify a particular point of view; this however is unacceptable because not every issue has an 'other side of story'. Tumposky (2004) gave an example of the Holocaust denial as an unreasonable position which is not suitable for debate.

The fourth, debate tends to encourage a confrontational atmosphere in the classroom, which is not suitable for some female students and certain students of particular culture who are 'uncomfortable with oppositional forms of communication' (Tumposky, 2004). Tumposky's criticisms may have some truths. However, she hastily discounted debate as an effective means to enhance critical thinking and oral speaking skills. Above all, she failed to take into account the fact that educators themselves are able to ensure the pitfalls of debate are minimized by creating a positive classroom environment during debate.

As discussed by Kennedy (2007), a number of scholars have sought to respond Tumposky's criticisms and offered several solutions to deal with those in-class debate's flaws. Elizabeth Musselman (2004) addressed the first criticism of Tumposky above. To mitigate the bias toward dualism, she assigned two to three students to be conciliators in each in-class debate of her history course. At some points through the in-class debate, these conciliators intercept by offering alternative or conciliatory positions to the bipolar views put forward by both the affirmative and negative teams. This Musselman's suggestion, however, has still possibly left some 
perspective out, thus other minor voices may not be well represented, and might lend disproportionate credibility to only three dominant perspectives (affirmative, negative and conciliatory positions).

Another scholar, Gary Hopkins (2003a) sought to overcome Tumposky's second and third criticism. He showed that debate does not necessarily end up in winning or losing positions and every issue may attract more than bipolar opinions. The best example he offered for this was a Four Corner Debate model. In this format, each of four corners of the classroom is labeled (1) 'strongly agree', (2) 'agree', (3) 'disagree' and (4) 'strongly disagree'. An instructor then writes on board a statement that provokes different opinions and reactions from students who then move to one of the four corners they decide to choose. The students who have selected the same corner then work together to present arguments for their position. After each group shares its position with the others, the floor is then opened for debate where the groups would "crossexamine" or question one another. Students may switch corners if their opinions have changed, but they have to explain why they decide to change positions. Finally, each group works to write a paragraph summarizing the strongest points supporting their position. Despite this model propounded by Hopkins (2003) is so flexible to allow students shift in their positions, it has some deficiencies. It not only can cause the inconsistency of students in adopting a position but also may lead to their lack of self-confidence in making a decision.

Tumposky's fourth criticism was responded by Lisa Elliot (1993). Elliot organised debate for her class on Psychology of Women in which she was grading students based on their participation rather than on performance. Moreover, instead of a criticism of in-class debates, Fisher et.al (2001) maintained that the confrontational character of in-class debate could be a potential benefit by which students can learn how to better handle conflicts outside of class. Additionally, Saskatchewan Curriculum Reference Committee (1998) pointed out that through this particular nature of debate students will know how to argue constructively while staying calm. These responses to Tumposky's criticisms were well said. However, they failed to recognise different behaviors of students and that the oppositional nature of debate could privilege verbally aggressive students and silence those students who are uncomfortable with argumentation.

By analyzing the strengths and limitations of those responses of Tumposky's criticism above, I don't mean that I concur with Tumposky's thought. What I am trying to do here is to point out that despite the pedagogical benefits of debate, one should bear in mind that any existing debate format is imperfect and it is educators' task to always seek out solutions and overcome problems in utilising debate as a learning teaching method.

\section{In-class debate as (in)effective educational method}

There are some works that focus on in-class debate and analyse its impacts for students. Kennedy's article (2007) provided a good study by offering criticisms and their rejoinders on the extent to which in-class debate has been (un)helpful for students to effectively enhance their skills and knowledge. Apart from what have been discussed before, three key issues of conducting and assessing in-class debate stand out in her analysis:

1) the issue that participation in an in-class debate will only reinforce a student's existing beliefs rather than promoting an objective analysis of an issue;

2) the issue that in-class debate cannot mobilise many students to participate in. This could mean, for the critics, that debate is not an 
active learning process since the rest of students only becomes an audience and they not necessarily get involved in the debate;

3) the issue of difficulty in assessing students' performance in-class debate especially because some debate team members may have contributed more to the effort than others.

Addressing the first issue above, Green and Klug's study (1990) supported this by stating that students who defended a position they already subscribed to from the very beginning were less likely to change their view, while students who argued a position they initially felt indifferent or oppositional often would change their opinion. Green and Klug, unfortunately, did not prescribe anything on how to tackle this problem. They both acknowledged that their work needs follow-up studies either through replication or else.

A number of scholars sought to deal with the problem revealed in Green and Klug's study. In order to overcome this problem, Budesheim and Lundquist (2000) suggested that students are requested to defend one position during the debate and to defend another position in a written assignment. They both further argued that the format of debate assignment should encourage students to consider the opposite, because only then are students likely to be more open to new perspectives and spend less time reinforcing old beliefs" (Budeheism and Lundquist, 2000). In fact, as unveiled by Keller, Whittaker and Burke (2001), interchangeable position (from affirmative to negative or vice versa) has resulted in persuading the shift in student's opinion on a given particular topic. A student was quoted saying "working on opposite side of my personal viewpoint was a very positive learning experience" (Keller, Whittaker and Burke, 2001). This kind of suggestions was very good. However, it must be bore in mind that because students should carry out two contending positions interchangeably, the amount of time devoted to this can detract from covering a wider scope of the course material. This point should be taken into account when this particular suggestion would be accommodated.

In dealing with the second issue, which is a purported weakness of in-class debate in bringing students as many as possible to actively engage in debate, some scholars such as Snider and Schnurer (2002), Roy and Macchiette (2005), Moeller (1985), (Landrum, 1991) and Temple (1997), suggested that instructors should require all students who are not participating orally to do an assignment, either by taking notes during the debate, by summarizing the arguments presented by both parties of debate or by disclosing their own position in writing supported by relevant evidence. Another suggestion to address this issue of student immobility is to require students to investigate both sides of the issue in question and to inform them about which side they will defend in the last minutes before the debate starts (Budesheim and Lundquist, 2000).

It is worth noting here that Gary Hopkins (2003b) proposed a new model of in-class debate to ensure equal opportunities for all students to get involved in debate that might otherwise be monopolized by certain students who have more advanced communication skills. This strategy is known as 'three card strategy' where the teacher provides each student with three cards on which are printed the words "Comment or Question." When a student wishes to make a point as part of the discussion, the student raises a card; after making a comment or asking a question pertinent to the debate, the student turns in the card. This strategy encourages participants to think before jumping in; those who are usually frequent participants in classroom discussions must weigh whether the point they wish to make is valuable enough to turn in a card. When a student has used all the cards, he or she cannot 
participate in the discussion again until all students have used all their cards.

To resolve the third issue, namely the problem of assessing students' participation in debate, scholars have offered different suggestions. On the one hand, some scholars found that the authority to assess all students' activities related to in-class debate was often given to instructors or teaching assistants. There were a variety of tools utilized by instructors to assess the students' performance including a rubric that contain categories such as analysis, evidence, organisation, delivery, and teamwork (Glantz and Gorman, 1997; Jugdev et.al., 2004; Snider and Schnurer, 2002; Darby, 2007). On the other hand, a number of professors suggested peers' evaluation to be used for assessing students' performance and their participation during in-class debate (Melvin, 1988; Smith, 1990; Morahan-Martin, 1996; Beck, 1999; Walker and Warhurst, 2000; Gibson, 2004). The aim was to reduce the subjectivity of individual assessment by an instructor alone. Most of these scholars discovered that the involvement of students in evaluating among themselves was proven positive and reliable. The so-called 'peer leniency' was closely monitored by the instructor to ensure that a reliable rating system is well functioned.

All works on debate assessment method described in the above paragraph did not distinguish between the performance of the group and of debate team member. Apparently, the work of Moeller (1985) was considered sufficient to deal with this particular issue. Moeller (1985) marked the performance of his students based on both an individual and team works. While individual grade depends on diction, eye contact, insight into the issue and overall effectiveness; team grade is based on their organisation, preparation, use of supporting evidence and use of rebuttal.
To my astonishment, only very few works address this important issue as to whether to assess the students' performance individually or as a team. I myself have encountered some difficulties when assessing students' performance for my in-class debate at University of Western Sydney, where I organised for the unit 'Contemporary Debate in Social Sciences' in 2013. To give students both an individual and a team grade at the same time they perform inclass debate proved to be difficult not only because each of students has a different role (moderator, debater, cross-examiner, researcher, note taker, etc.), but also given that each role has no similar weight. For this reason, I marked my students based on their teamwork from the preparation and the performance in in-class debate. I was not sure if this were objective enough and I had created justice for each of the debate team members. Perhaps, a comprehensive and a meticulous study to closely look at into this particular issue are badly needed.

\section{References}

Beck, C. (1999). Francine, kerplunk, and the golden nugget - Conducting mock trials and debates in the classroom. Social Studies, 90 (2), 78-84.

Budesheim, T., \& Lundquist, A. (2000). Consider the opposite: Opening minds through in-class debates on course-related controversies. Teaching of Psychology, 26 (2), 106-110.

Busmek, P. (2009). Debate as Disease: Debate and the Dialogue and Deliberation Movement, Contemporary Argumentation and Debate 29 (1), 1-30.

Darby, M. (2007). Debate: A teaching-learning strategy for developing competence in communication and critical thinking. Journal of Dental Hygiene, 81(4), 1-10.

Ehninger, D. (1958). Debating as critical deliberation. Southern Speech Journal, 24 (1), 22-30. 
Elliot, L. (1993). Using debates to teach the psychology of women. Teaching of Psychology,

20 (1), 35-38.

Fisher, M., LaPointe, C., Peterson, K., \& White, D. (2001). Using debate to develop empowered learning in the classroom: A prescription. Retrieved July 21, 2014, from

http://debate.uvm.edu/NFL/rostrumlib/Sn ider\%20Empow.pdf

Flick, D. (1998). From debate to dialogue: Using the understanding process to transform our conversations. Boulder, CO: Orchid Publications.

Freeley, A., \& Steinberg, D. (2005). Argumentation and debate: Critical thinking for reasoned decision making (11th ed. ). Belmont, CA: Wadsworth.

Gibson, R. (2004). Using debating to teach about controversial drug issues. American Journal ofHealth Education, 35 (1), 5253.

Glantz, S., \& Gorman, B. (1997). "He said, she said" debating with technology. TechnologyConnection, 4 (7), 14-16.

Green, C., \& Klug, H. (1990). Teaching critical thinking and writing through debates: Anexperimental evaluation. TeachingSociology, 18 (4), 462-471.

Hopkins, G. (2003a). Four corner debate. Retrieved July 21, 2014, from http://www.educationworld.com/a_lesson/ 03/lp304-04.shtml

Hopkins, G. (2003b). Stage a debate: A primer for teachers on the Lincoln-Douglas debate format. Retrieved July 21, 2014, from

http://www.educationworld.com/a_lesson/ 03/lp304-01.shtml

Jugdev, K., Markowski, C., \& Mengel, T. (2004). Using the Debate as a Teaching Tool in theOnline Classroom. Online Cl@ssroom, 1 (10), 4-6.

Keller, T., Whittaker, J., \& Burke, T. (2001). Student debates in policy courses:
Promoting policypractice skills and knowledge through active learning. Journal of Social Work Education, 37 (2), 343-355.

Kennedy, Ruth (2007). Tin-class debates: Fertile ground for active learning and the cultivation of critical thinking and oral communication skills. International Journal of Teaching and Learning in Higher Education, 19(2), 183-190.

Landrum, R. (1991). Student evaluation of classroom debates. College Student Journal, 25 (2), 163-165.

Melvin, K. (1988). Rating class participation: The prof/peer method. Teaching of Psychology. 15(3), 137-139.

Moeller, T. (1985). Using classroom debates in teaching Developmental Psychology. Teaching of Psychology, 12 (4), 207-209.

Morahan-Martin, J. (1996). Should peers' evaluations be used in class projects? Questions regarding reliability, leniency, and acceptance. Psychological Reports, 78(1), 143-150.

Musselman, E. (2004). Using structured debate to achieve autonomous student discussion. TheHistory Teacher, 37 (3), 335-348.

Roy, A., \& Macchiette, B. (2005). Debating the issues: A tool for augmenting critical thinkingskills of marketing students. Journal of Marketing Education, 27 (3), 264-276.

Saskatchewan Curriculum Reference Committee.(1998). Communication studies 20 module 7: The art of debating. Retrieved July 21, 2014, from http://www.sasked.gov.sk.ca/docs/comm2 0/mod7.Html

Schroeder, H., \& Ebert, D. (1983). Debates as a business and society teaching technique. Journalof Business Education, 58, 266269.

Smith, R. (1990). Are peer ratings of student debates valid? Teaching of Psychology, 17 (3), 188-189. 
TARBIYA: Journal of Education in Muslim Society, 2(1), 2015

Snider, A., \& Schnurer, M. (2002). Many sides: Debate across the curriculum. New York: International Debate Education Association.

Tannen, D. (1998). The argument culture: Stopping America's war of words. New York: Ballantine.

Temple, M. (1997). Using debate to develop health literacy. Journal of School Health, 67 (3), 116-117.
Tumposky, N. (2004). The debate debate. Clearing House, 78 (2), 52-55.

Walker, M., \& Warhurst, C. (2000). "In most classes you sit around very quietly at a table and getlectured at ...": Debates, assessment, and student learning. Teaching in Higher Education, 5 (1), 3349. 